\title{
Gratitude to God: Jonathan Edwards and the Opening of the Self
}

\author{
KYLE STROBEL \\ Biola University, USA \\ Kyle.C.Strobel@Biola.EDU \\ ORCID: 0000-0003-3204-866
}

\begin{abstract}
The study of gratitude has become an increasingly important topic among psychologists to address the nature of human flourishing. Of more recent interest is how gratitude to God specifically functions within an account of human flourishing, with theologians seeking to provide a distinctively Christian account of the nature of gratitude. This article enters into the ongoing conversation by attending to Jonathan Edwards's (1703-1758) theological anthropology and development of natural and supernatural gratitude. In particular, Edwards's anthropology includes within it an account of how the self can, and should, enlarge to receive another in love. This "enlargement" is the creaturely mirror of God's self-giving and is the supernatural response to the creature who has received God's grace and been infused with divine love. As a supernatural response based on God's action in the soul, this account of gratitude differs from its natural counterpart. In keeping with Edwards's account, therefore, there is a need to develop studies that differentiate natural and supernatural gratitude. Furthermore, this article ends with a suggestion for a study that could pick up this task based on recent psychological studies that attend to how gratitude affects self-relation. On Edwards's account of the enlargement of the self, as well as his notion of supernatural gratitude, there is meaningful research to be done on how these can help assess development in the formation of gratitude and human flourishing.
\end{abstract}

Keywords: Anthropology; Supernatural Virtue; Infused Virtue; Self-Relation. 


\section{Introduction}

The study of gratitude has advanced over the past several decades among psychologists, but gratitude to God, the main interest of theologians studying gratitude, has not been a central focus. Furthermore, while theological accounts of gratitude are often subsumed under other foci in moral theology, theologians have more recently followed the trajectory of psychologists to address gratitude in its own right (Leithart 2014). For both psychologists and theologians, the question of gratitude to God specifically, and how that may or may not differ from human-to-human gratitude (or human-to-object gratitude) has become a pressing line of inquiry. Furthermore, focusing more specifically on the discussion of gratitude in the Christian tradition, discerning the difference between natural and supernatural gratitude is particularly pressing. To address this tradition in light of recent accounts, I turn to Jonathan Edwards's development of the self and love within his anthropology, using that material to exposit natural and supernatural gratitude. I conclude by reflecting on the psychological material on gratitude with a focus on how gratitude to God might be studied.

Jonathan Edwards (1703-1758) is generally considered one of the greatest theological and philosophical minds to have worked in North America. While little has been done on Edwards's theological anthropology as such, anthropology is a central theme in his corpus, as is seen in his work on religious psychology in Religious Affections, freedom and morality in Freedom of the Will, love in Charity and Its Fruits, and virtue in light of God's being and action in the Two Dissertations (see also Martin 2019 and Strobel 2017). Along with his astounding output of sermons and notebooks, Edwards provides a wealth of material on how human persons can and should respond to God, making him a particularly interesting figure to utilize to consider gratitude to God. To do so, this essay moves in two major parts. Part I addresses Edwards's conception of the self and the necessity for the self to be "displaced" by God. Part II looks at how Edwards understands gratitude in relation to this displacement of the self, and how this displacement is a necessary feature of what Edwards thinks 
of as supernatural gratitude. The essay concludes by suggesting a research direction that could be explored in light of Edwards's construction.

\section{The Displacement of the "Self"}

Edwards's account of anthropology includes within it the notion of a "reciprocating self," to adapt a contemporary psychological notion (see Balswick and Balskwick 2016). On his view (unlike how "reciprocating self" is typically used), a self naturally and necessarily stands in relation to itself, subjectifying itself by projecting a mirror image by which it can attend to itself (creating a context of self-relation for the sake of otherrelations) (Kierkegaard has a similar notion, see Kierkegaard 1980, 13). He states,

Man is as it were two, as some of the great wits of this age have observed: a sort of genius is with a man, that accompanies him and attends him wherever he goes; so that a man has a conversation with himself, that is, he has a conversation with his own idea. So that if his idea be excellent, he will take delight and happiness in conferring and communing with it; he takes complacency in himself, he applauds himself; and wicked men accuse themselves and fight with themselves as if they were two. And man is truly happy then, and only then, when these two agree, and they delight in themselves, and in their own idea and image, as God delights in his. (WJE 13: 260 - my emphasis)

By concluding that this self-relation is a part of humankind's being created in the image of God, Edwards reveals how central this is for his understanding of personhood, divine or human. Furthermore, as an aspect of the image of God in humanity, this construct is directly connected to how human persons relate to God, and what it means to flourish in one's humanity.

The "self," for Edwards, at its most primal, is an "I-I" relation (see Coe and Hall 2010, 222-223 for a similar notion). A person naturally loves themselves, and therefore stands in relation to themselves. But this inner-relation is not a narcissistic bent inwards, at least not necessarily, but this love is meant to be "enlarging." This is the difference between proper 
self-love and selfishness. In Edwards's words, "Selfishness is a principle which does, as it were, confine a man's heart to himself. Love enlarges it and extends it to others. A man's self is as it were extended and enlarged by love. Others so far as [they are] beloved do, as it were, become parts of himself." (WJE 8: 263) Furthermore, "yet this is not selfishness, because it is not a confined self-love, because his self-love flows out in such a channel as to take in others with[in] himself. The self which he loves is, as it were, enlarged and multiplied, so that in those same acts wherein he loves himself he loves others." (WJE 8: 258) Edwards's account is one of internalizing relations, whereby one loves others into union with oneself. Since relationality is intrinsic to Edwards's notion of a "self," it is not merely love, but the self that can enlarge to receive others.

The upshot of this account is its ability to make sense of the biblical language of loving one's neighbor as oneself (Mark 12: 31), opening wide one's heart (2 Cor. 6: 11), and making room in one's heart for another (2 Cor. 7: 2). The difficulty, at first glance, is how one can appropriately love God. One might think, based on this construct, that to love God is to contain, rather than receive God. Furthermore, by starting with self-love, one might wonder if the love of God is secondary in Edwards's thinking. Edwards demurs: "Self-love, taken in the most extensive sense, and love to God, are not things properly capable of being compared one with another: for they are not opposites, or things entirely distinct; but one enters into the nature of the other." (WJE 18: 74) Whatever it entails for one of these to "enter into the nature of the other," Edwards is clear that love of God cannot "arise from self-love." (WJE 2: 242) This raises the question: How can the love of God be foundational without undermining his basic construct of expanding self-love?

Edwards's solution entails what I call the "displacement of the self." Once again, the biblical material is close to the surface. Jesus claims, "For whoever would save his life will lose it, but whoever loses his life for my sake will find it." (Matt. 16: 25) Furthermore, Paul declares, "I have been crucified with Christ. It is no longer I who live, but Christ who lives in me. And the life I now live in the flesh I live by faith in the Son of God, who loved me and gave himself for me." (Gal. 2: 20) On Jesus' teaching, losing 
one's life is required for finding one's life, just as with Paul's image, to be crucified with Christ results in the "I" no longer living, even though he immediately reasserts the "I" that now lives (see Eastman, 2017, 6-7 for an insightful discussion). For both there is a regrounding of the "I" that takes place only after losing the "I." This is where Edwards's I-I construct helps to make sense of losing one's self for the sake of finding one's self.

On Edwards's view, the second "I," what we might think of as the "projected I," needs to be displaced, such that the "primal I" discovers itself, not in a self-relation first and foremost, but in relation to God (again, Coe and Hall, 2010, 264-265 is relevant here). A person must discover more than forgiveness in Christ, they must discover themselves in Christ. To consider oneself is no longer to ground oneself in relation to oneself, because this is not ultimately defining for the Christian. Rather, one must discover their lives lost and regained in Christ. Edwards states,

As the new nature is from God, so it tends to God as its center; and as that which tends to its center is not quiet and at rest, till it has got quite to the very center, so the new nature that is in the saints never will it be at rest, till there is a perfect union with God and conformity to him, and so no separation, or alienation, or enmity remaining. The holy nature in the saints tends to the fountain whence it proceeds, and never will be at rest, till the soul is fully brought to that fountain, and all swallowed up in it. (WJE 19: 692)

In Edwards's depiction of regenerate humanity, the true self is the self lost in God such that she is found in God. Being "swallowed up" in God is not an annihilation of the self, but is the ground upon which one discovers true human freedom and life.

The mirror one stands before in the subjectification of the self (i.e., the "projected I"), is no longer established in the self, but is alien to the self. One stands before Christ, and discovers themselves in Christ. This can happen only if a person first stands before God as God truly is, in all of his fullness and freedom, finding no resources internal to the self to placate or somehow manipulate God. The shift from God in his infinite fullness and impenetrability to God for me is what is known in regeneration, where fearing God is recognized as the beginning of wisdom, while 
also affirming that perfect love casts out fear (1 John 4: 18). Knowing both this fear and this love, one's fundamental subjectification shifts; the self is displaced from the center, no longer grounding itself with an internal mirroring of the self, but one now knows themselves mirrored back in Christ (this is the dark mirror of faith in 1 Cor. 13: 12). By faith the regenerate discovers another face in the mirror - the face of Christ - and come to see themselves only from within that gaze. The internal mirroring of the self in the I-I relation now has an external pole, such that their true self is not a mere projection, but is the "I" that is hidden with Christ in God (Col. 3: 3). But it is not only that their I-I reciprocity now includes Christ, where they see themselves truly only in the face of Christ. Even more so, they are who they are as they are seen by another. In this sense, the call is not only to know God, and to know oneself in God, but to be seen and known by God from within his redemptive gaze (cf. Gal. 4: 9, 1 Cor. 13: 12). This, of course, is an objective reality that requires a subjective appropriation. Christians still turn, in the flesh, to ground themselves in and through their projected self. But while it is possible to continue to walk in the flesh rather than in the Spirit, this is no longer the truth of their person (Gal. 5: 16).

On Edwards's account, to be displaced by love and placed in Christ is a singular movement of the Spirit that reconstitutes the person in regeneration (see Strobel 2013, 196-207 for the Spirit's work on the soul in Edwards's theology). One's self has become incorporated in Christ, and therefore it is the Father's gazing upon the believer in the Son, and the fact that Christ now defines their life before the Father, that is the defining feature of the person's life. This is precisely why they must come to gaze upon themselves in Christ to appropriate the truth of this reality. The Father's love upon his perfect image (i.e., Jesus) is enlarged to receive his creatures as members of his person. Finding oneself in Christ, is discovering oneself internal to the Father's love of the Son. This is the love that buoys the self, and this is the love that regrounds the I-I relation so that it can enlarge with that same love that upholds it. By seeing and being seen, the self comes to know that one is defined as a "thou" prior to being an I, because the center of one's being is in God. The fallen self function- 
ing in the flesh seeks to construct a grounding in itself and from within its self-relation (for Kierkegaard, this is the self in despair, Kierkegaard, 1980, 68-69). This is the incurvatus in se that is the result of the Fall. But in regeneration, the person stands before the face of Christ as the beloved "thou" of the Father, and in God's regenerating action is infused with the love of God - the Father's love upon the Son (John 17: 26) - into the soul. In Edwards's words, "when the Spirit of God enters into the soul, love enters. God is love, and he who has God dwelling in him by his Spirit will have love dwelling in him. The nature of the Holy Spirit is love; and it is by communicating himself, or his own nature, that the hearts of the saints are filled with love or charity. Hence the saints are said to be "partakers of the divine nature" [2 Peter 1: 4]." (WJE 8: 132)

The regenerate soul discovers a more foundational mirror than the one the fallen self stands before. This is the mirror of faith, and therefore is the face-to-face recognition of Christ himself as the defining reality of one's personhood (cf. 1 Cor. 13: 12, 2 Cor. 4: 6). In this state, the mirror of one's person is no longer a projection of an ideal self (which is constructed by the "natural man"), but is the "I" hidden in Christ and seen as beloved by the Father. This new foundation of the soul in God allows the "self" to enlarge to receive another, as one is being formed into the likeness of God in his self-opening. The act of God to internalize his creatures in his self love establishes the trajectory for coming to see my neighbor, not external to my self, but internal to my self-in-Christ (McFadyen highlights Edwards's instinct well, see McFadyen 1990, 151). In other words, as I recognize God in his self-giving, coming to know the depths of his grace, my heart responds to others as he has responded to me (see Matt. 18: 21-35). In this sense, God's presence in my soul reorders my soul around God and his love such that I am able to open to others in love and kindness. But this objective reality (i.e., God in his self-giving) has a subjective counterpart: gratitude to God. Without gratitude, the self has not fully embraced the self-giving of God. But on Edwards's view, this raises the question for how gratitude might relate to the new I-Christ-I relationality of seeing and knowing oneself in Christ, and knowing gratitude to God as the overflow of God's self-giving. 


\section{Gratitude to God}

In light of the above exposition of Edwards's notion of the self, I turn now to address how gratitude relates to the self and to love, both in general and in gratitude to God more specifically. As a virtue, gratitude will be addressed according to Edwards's overarching taxonomy of the virtues. Following a relatively traditional account, at least in its broadest movements, Edwards articulates gratitude as either natural or supernatural. For instance, someone who is unregenerate still enlarges in love to internalize another person in their self-loving. That, in and of itself, is not distinctively Christian, although the nature of that internalization and self-relation will change for the regenerate. This means that natural gratitude is a good that is possible for any person, Christian or not, and is something that can be "acquired" (i.e., habituated) through various sorts of practices. This is truly good and meaningful, in a certain sphere, but this sphere is limited because it does not include God in its purview (see WJE 8: 540 for how Edwards orients this in relation to beauty). Supernatural gratitude, on the other hand, is gratitude that stems from God's presence, love, and holiness in the soul by the Spirit (Tom Greggs' discussion of grace and gratitude is helpful here, Greggs 2017, 147-148). This is based on the infusion of grace into the person, such that love is the new foundation for all virtuous action. "Love," as understood here, is not a generic notion, but is divine, as it is the eternal love of the Father upon the Son, namely the Spirit, now infused into the human being. To consider gratitude, therefore, we attend first to natural gratitude and then to supernatural.

\subsection{Natural Gratitude}

As a general rule, Edwards recognizes that gratitude is an important human virtue (Edwards 1743). "Ingratitude," Edwards asserts, "is especially odious," and then goes on to quote a "saying of the heathen" with approval: "Call me ungrateful and call me all that is bad, [it is] impossible there should be a more odious character given a man than that he is ungrateful" (Edwards 1743). Furthermore, Edwards continues, the "kind of 
congruity and harmony that there is between a receiver and benefactor, which we call gratitude, is especially amiable and lovely" (Edwards 1743). In using the language of aesthetics, Edwards is employing an important aspect of his overall theology that sees union of one person to another as the nature of beauty, first in God's triune life, secondly in God's relationship with his creatures, and then thirdly among human persons themselves. Gratitude, in this sense, is beautiful as it is the proper harmony between two moral agents - one in benevolence offering kindness and the other receiving and reciprocating through gratitude. Ingratitude, therefore, is a rejection of this beauty for disorder, because it rejects the harmony that God has instilled in creation. This link with beauty will be particularly important for supernatural gratitude, because one must recognize the generosity for which one is grateful. For someone to have gratitude to God, we will see, one must recognize what God has done in light of who he is, a recognition only available in Christ by the illumination of the Spirit.

Natural gratitude, then, is simply a natural human response to recognizing someone's kindness to them. "Men are disposed to gratitude for any kindnesses they receive from those they love." (WJE 8: 134-135) This is why being ungrateful is so despicable. To be ungrateful is to refuse to recognize the truth of an act as an act of kindness. Gratefulness comes from the recognition of a kindness, but, for Edwards, it is not just any kindness, but kindness from one who is loved (a kindness from one not loved may still be responded to with gratitude, but it will be substantially less than to one loved). We can summarize Edwards's view of gratefulness in three key features that determine how someone properly responds in gratitude. A proper response is based upon: 1. the degree of the kindness upon a person, 2. the relationship between you and the giver of the gift, and 3. the nature of the love you have for them (see WJE 8: 617). Each of these three features will change the nature and expectations of the gratitude offered in response. However, the response is based on the perspective of the receiver, who will be held accountable to recognize the truth concerning each of these three factors. For supernatural gratitude to God, 
this will require an illumination of the Spirit, so that the receiver of God's kindness will come to see the truth and respond appropriately.

\subsection{Gratitude to God}

By focusing my attention on gratitude to God, it is important to note that there are two main options for what this might mean. For the sake of clarity, I am not interested in this essay in what I call a natural gratitude for God. This kind of gratitude is still gratitude, and it is still gratitude to God, but it is gratitude to God that is not ultimately constructed on God in himself, God pro me, and God's act to make me holy as he is holy. This is the kind of gratitude someone without supernatural grace might have for God who, in distress, calls out for divine help, and when things work out, shows a degree of thankfulness. With any kind of gratitude, as noted above, the nature of the kindness, the relationship, and the love between you and the one giving the gift will determine whether one's response can be considered grateful or ungrateful. Admittedly, Edwards will, at times, talk about natural gratitude not needing real relationship. But what this means is that there is a spectrum in all gratitude where the relationship (or lack thereof) has a direct correlation to the expected response of gratitude. Take for instance, Edwards's claim in True Virtue:

Natural gratitude, though in every instance wherein it appears it is not properly called love, because persons may be moved with a degree of gratitude towards persons on certain occasions, whom they have no real and proper friendship for, as in the instance of Saul towards David, once and again, after David's sparing his life, when he had so fair opportunity to kill him: yet it has the same or like operation and effect with friendship, in part, for a season, and with regard to so much of the welfare of its object, as appears a deserved requital of kindness received. And in other instances it may have a more general and abiding influence, so as more properly to be called by the name of love. So that many times men from natural gratitude do really with a sort of benevolence love those who love them. From this, together with some other natural principles, men may love their near friends, love their own party, love their country, etc. (WJE 8: 610). 
But this is not our primary focus. Focusing on our notion of a supernatural gratitude to God, Edwards's view shows how essential each of these three features are: 1. Degree of kindness: the nature of God's self-giving sacrificial love as, in a sense, infinite; 2 . The relationship between giver and receiver: God gives himself and opens his life of love, not because of the goodness of the creature, but through his grace (see WJE 19: 185); and 3. The nature of love you have for God: the love that is offered is perfect, as it is the love of the Father upon the Son given to believers as they are called into the Father-Son relation (John 17:26), and is poured into the soul by the Spirit (Rom. 5: 5). While the nature of gratitude cannot be perfect to "match" God's work, the call is to love God with one's whole being (Matt. 22: 37), sharing in the vicarious work of Christ for us (see WJE 8:580 for how one could be grateful to an object). This is the main foundation of gratitude to God, upon which all other grateful acts are understood. It is not surprising, therefore, that discussions of salvation are key places in Edwards's corpus where he advances an account of gratitude and ingratitude (for this instinct, see Greggs 2017, 147).

Recalling the displacement of the self, we can recognize how gratitude to God takes on a different reality than natural gratitude (for how "unselfing" and humility are central to this in the Christian tradition, see Dunnington 2019). It is imperative for the Christian to know that their lives are hidden with Christ in God, but that is not the first move of the Christian in regeneration. There is a movement that takes place, even if only logically (rather than temporally), to see God in himself prior to seeing him for me. One stands before the penetrating glare of God - before the infinite truth of his glory, holiness, and justice - and then understands that this penetrating glare of God is upon Christ, the perfect one, in whom my life is hid. This is fundamental: "this is indeed the very main difference between the joy of the hypocrite, and the joy of the true saint," Edwards avers. "The former rejoices in himself; self is the first foundation of his joy: the latter rejoices in God." (WJE 2: 249) There is an ordering necessary in one's gratitude to God that highlights whether or not the gratitude is merely natural or if it is truly supernatural. One must recognize God in himself, apart from his self-giving, to understand the degree 
of graciousness in that self-giving. This is where the fear of the Lord is secured. Only by recognizing God in himself - in his immutability, impassibility, and infinity - can one truly grasp who he is pro me. Promeity needs to be the superstructure that is built upon the foundation, which is God's goodness, holiness, and beauty in himself. If it is the other way around, then one seeks God, not because he is God, but because one hopes he can be used to advance their own agenda. (WJE 2: 251)

To embrace supernatural gratitude necessitates that one share in God's own self-love - that the love by which God loves himself is infused into one's soul. The key element of this supernatural gratitude, as opposed to natural gratitude, is the "foundation laid before," namely, "love to God for what he is in himself." (WJE 2: 247) Edwards claims that prior relationship matters to the nature of gratitude. (WJE 2: 247-248) This "prior relationship" includes knowing God in himself and knowing him for me, but also coming to understand the nature of the kindness given. As we have seen, proper gratefulness is the response to a kindness based upon: 1 . The degree of kindness, 2 . The relationship between giver and receiver, and 3 . The nature of love you have for the giver. In supernatural gratitude to God, the degree of kindness is governed by God's self-giving in Christ Jesus, and his embracing even death itself for your sake. The relationship is one where God both gives himself and enlarges himself to receive you within his own self-love. Both of those features are objective realities that call for a subjective embrace of this grace. The third feature, the love you have for God, is called into being through the love of God being poured forth into your soul by the Spirit (Rom. 5:5). The relationship is one of self-enlarging by God, as well as self-giving to you, that he is now the center of your person and the ground of your own reciprocal self-enlargement. You see yourself in Christ as you are seen by the Father within his Son. The foundation of gratitude in the soul, therefore, is the fullness of God's life given and embraced by the one who has come to see and know God in his grace.

This reciprocal movement of gratitude, we might say, is imbedded in the enlargement of the heart to another - both in natural gratitude and in supernatural gratitude. Going back to the biblical language, when 
Paul tells the Corinthian church that their affections restrict their hearts (2 Cor. 6:12), we can now see how that works. A heart's inability to enlarge is directly related to the three necessary realities for true gratitude. On Edwards's anthropology there is a direct connection between opening one's heart to receive another - which is the proper end of human flourishing - and gratitude, because it is the grateful heart that can open to others. There is a necessary formation and development to this human capacity, which means that the soul needs to be reordered in its affection. To reorder these affections and respond appropriately will entail a proper recognition of the kindness given, the relationship with the giver, and the love that you have received and wish to rebound to the giver. To overflow in love, is to be reordered to the truth of grace - to recognize the kindness given, the nature of God's self-giving, and to know his love pour forth from and through you. Only this can reorder the affections that restrict the heart.

\section{Conclusion: The Study of Gratitude}

Edwards's primary interest in gratitude is not as a mere movement of the psyche, but as a virtue. Moral gratitude, on Edwards's conception, is the response to a gracious act that enlarges the self, which is why virtuous gratitude, of the natural or supernatural variety, needs to be based on love. In supernatural gratitude, one comes to embrace God in his selfgiving and reciprocate by opening oneself to God and to the things of God. Proper gratitude is not merely a response to God, but is a response in kind, an opening of the self to God who has opened himself in love to you. Importantly, given the telos of human personhood, this makes gratitude a core feature of embracing one's humanity. This requires an embrace of a new center and foundation external to the self that grounds the self, such that one can live from the truth that one's life is hidden with Christ in God. This relocation of the self in God, and the gift of a new self - a forgiven, free, and redeemed self - allows one to fully embrace the call to love one's neighbor as oneself as an overflow of gratitude for the love of God. 
In light of our above analysis, how might Edwards's view speak into the contemporary study of gratitude? Two clear lines come to the fore: First, there is a need to address and differentiate between natural and supernatural gratitude. In natural gratitude to God, there is real gratitude, but it is gratitude for a god whose life has not been received by grace, but who has offered some form of providential kindness upon you (or, we could say, it is gratitude to a god distant and removed from your person). We have seen that gratitude to God is discovered through God's grace in salvation, itself resting on the fullness of God's self-existence (i.e., God's aseity). This gratitude is an essential feature of faith, and receiving God and reciprocating that self-giving love creates a new relation to ground the self. This, however, is an objective reality that needs subjective appropriation. This raises questions concerning Christian formation. If a Christian is one who has been objectively displaced from the center of their self and re-grounded in Christ, then Christian formation will include the subjective appropriation of that reality. A Christian, no doubt, is still able to live in the flesh and attempt to secure the foundation for their self in a self-relation. But this would be antithetical to the nature of God's self-giving (i.e., it would not be an appropriate response of gratitude). In light of this, a second line of inquiry would focus on spiritual maturity by attending to self-relation in light of one's relation to God.

Studies abound looking at gratitude according to a natural anthropology and vision of human flourishing, but the further question of self-relation has been attended to as well. (A study looking into the different phenomenology of acquired vs. infused gratitude would be an interesting, and important, study in its own right.) In their study on the impact of gratitude on depression and anxiety, Petrocchi and Couyoumdjian looked at the role gratitude played in how one relates to themselves. In their words,

Self-criticism has been described as a 'reflexive psychological behavior' (Whelton \& Greedberg, 2005), which entails not only a self-blaming attributional style, but also maladaptive, negative thoughts about the self, affective states (anger, disgust, contempt, disappointment for the self), and action tendencies (correcting, or punishing and attacking the self; Gilbert et al., 2004). 
To our knowledge, the link between gratitude and self-criticism had not been directly explored yet (Petrocchi and Couyoumdjian 2016, 193-194).

In their discussion of their findings, they note the role that gratitude played in helping people relate positively to themselves, not necessarily in undermining self-attacking and forms of self-criticism, but in having an "increased ability to reassure and encourage the self, and to attenuate a sense of self-inadequacy in front of failures" (Petrocchi and Couyoumdjian 2016, 200). Likewise, regarding anxiety, "grateful people experience less anxiety mostly because they are able to encourage and be compassionate and reassuring toward themselves when things go wrong in life" (Petrocchi and Couyoumdjian 2016, 200).

This study is particularly interesting because it points to the fact that gratitude is regarded as a virtue promoting prosocial behavior, while highlighting the role that self-relation has in prosocial behavior and in psychological health (Petrocchi and Couyoumdjian 2016, 201). Reflecting on their study, Petrocchi and Couyoumdjian claim, "The present findings show that gratitude is also associated with an improved 'relationship with the self,' in the form of a more positive and compassionate way of treating ourselves when things go wrong in life, which partially explains why grateful people are also less depressed and anxious." (Petrocchi and Couyoumdjian 2016, 201). With gratitude to God, understood as an infused virtue, we are not as directly interested in these constructs of human flourishing. Rather, attending to the possibility of using gratitude to God as providing markers of spiritual growth, we would need to employ a different set of categories. How one relates to themselves would now need to be understood by how one stands in relation to God and how one embraces (or doesn't) that relation. For instance, Paul declares that he does not judge himself, and it is God who judges him (1 Cor. 4:3, 5). His self-judging is not necessary because he stands before God. In a similar way that Paul can simultaneously reject the law and confirm that believers are fulfillers of it (Gal. 5:18; 6:2), Paul does not judge himself and yet can confirm that "I am not aware of anything against myself" (1 Cor. 4:4). By not seeking a new self-relation, even a healthy one, Paul discovers one 
in relation to God that grounds his self, such that the relation he has to himself is understood in and through God.

A study of this sort would focus on self-confessing Christians, and would need to attend to: 1 . The person's strategies for self-relation (selfcriticizing, self-attacking, or self-reassuring to use Petrocchi's and Couyoumdjian's categories), 2. How they understand the God-self relation (attending to whether or not they understand the nature of the gift God has given them in giving himself to them by grace), and 3. How their gratefulness to God has been formed and embraced. In particular, for this final point, a question about whether God's promeity serves as the only foundation for God's action, or if God in se is the more primal foundation for God's self-giving love, would need to be assessed.

\section{References}

Balswick, Jack O., Palema Ebstyne King and Kevin S. Reimer. 2016. The Reciprocating Self: Human Development in Theological Perspective. 2nd Edition. Downers Grove, IL: InterVarsity Press.

Coe. John H., and Todd W. Hall. 2010. Psychological in the Spirit: Contours of a Transformational Psychology. Christian Worldview Integration Series. Downers Grove, IL: InterVarsity Press.

Dunnington, Kent. 2019. Humility, Pride, and Christian Virtue Theory. Oxford Studies in Analytic Theology. Oxford: Oxford University Press.

Eastman, Susan Grove. 2017. Paul and the Person: Reframing Paul's Anthropology. Grand Rapids, MI: Eerdmans.

Edwards, Jonathan. 1743. Sermon 39. Ps. 147:1 (edited), in Sermons, Series II, 1723-1727 accessed October 7, 2020:

http://edwards.yale.edu/archive?path=aHR0cDovL2Vkd2FyZHMueWFsZS51ZH UvY2dpLWJpbi9uZXdwaGlsby9nZXRvYmplY3QucGw/Yy40MDoxNC53amVvLjgyODUyOQ==

Edwards, Jonathan. 1959. Religious Affections. Edited by John E. Smith. The Works of Jonathan Edwards. Vol. 2. New Haven: Yale University Press.

Edwards, Jonathan. 1989. Ethical Writings. Edited by Paul Ramsey. The Works of Jonathan Edwards. Vol. 8. New Haven: Yale University Press. 
Edwards, Jonathan. 1992. Sermons and Discourses, 1720-1723. Edited by Wilson H. Kimnach. The Works of Jonathan Edwards. Vol. 10. New Haven: Yale University Press.

Edwards, Jonathan. 1994. The "Miscellanies": A-500. Edited by Thomas A. Schafer. The Works of Jonathan Edwards. Vol. 13. New Haven: Yale University Press.

Edwards, Jonathan. 2000. The "Miscellanies": Entry Nos. 501-832. Edited by Ava Chamberlain. The Works of Jonathan Edwards. Vol. 18. New Haven: Yale University Press.

Edwards, Jonathan. 2001. Sermons and Discourses, 1734-1738. Edited by M. X. Lesser. The Works of Jonathan Edwards. Vol. 19. New Haven: Yale University Press, 2001.

Edwards, Jonathan. 2003. Writings on the Trinity, Grace, and Faith. Edited by Sang Hyun Lee. The Works of Jonathan Edwards. Vol. 21, New Haven: Yale University Press.

Edwards, Jonathan. 2006. Sermons and Discourses, 1743-1758. Edited by Wilson H. Kimnach. The Works of Jonathan Edwards. Vol. 25. New Haven: Yale University Press.

Emmons, Robert A. 2004. “The Psychology of Gratitude: An Introduction.” In The Psychology of Gratitude, edited by Robert A. Emmons and Michael E. McCullough. Oxford: Oxford University Press.

Greggs, Tom. 2017. "In Gratitude for Grace: Praise, Worship and the Sanctified Life," Scottish Journal of Theology 70: 147-48.

Kierkegaard, Søren. 1980. The Sickness Unto Death: A Christian Psychological Exposition For Upbuilding and Awakening, edited and translated by Howard V. Hong and Edna H. Hong. Princeton: Princeton University Press.

Leithart, Peter. 2014. Gratitude: An Intellectual History. Waco, TX: Baylor University Press.

Martin, Ryan. 2019. Understanding Affections in the Theology of Jonathan Edwards: "The High Exercises of Divine Love”. London: Bloomsbury.

McFadyen, Alistair I. 1990. The Call to Personhood: A Christian Theory of the Individual in Social Relationships. Cambridge: Cambridge University Press.

Petrocchi, Nichola and Alessandro Couyoumdjian. 2016. "The Impact of Gratitude on Depression and Anxiety: The Mediating Role of Criticizing, Attacking, and Reassuring the Self.” Self and Identity 15: 193-194.

Strobel, Kyle C. 2013. Jonathan Edwards's Theology: A Reinterpretation. T\&T Clark. Strobel, Kyle C. 2017. "Being Seen and Being Known: Jonathan Edwards's Theological Anthropology.” In The Global Edwards, edited by Rhys Bezzant. Eugene: Wipf \& Stock. 